\title{
Effects of Synthetic Cannabinoids (JWH-018) on Antibody Response to HBV Vaccination
}

\author{
Sentetik Kannabinoidlerin (JWH-018) Hepatit B Asslamasina Antikor Yamitı Üzerindeki Etkisi
}

\section{Serkan KÖKSOY* ${ }^{*}$ (D) Aynur BAŞALP ${ }^{2}$ (D)}

${ }^{1}$ Burdur Mehmet Akif Ersoy University, Faculty of Halth Sciences, Department of Nursing, Burdur, Turkey ${ }^{2}$ Burdur Mehmet Akif Ersoy University, Faculty of Halth Sciences, Burdur, Turkey

\begin{abstract}
Synthetic cannabinoids can affect the immune system and can cause some changes in immune response. The immune response to the Hepatit B vaccine is complex. Studies on hepatitis B vaccine antibody response and JWH-018 are extremely limited. The main aim of this study was to investigate the effect of JWH-018 on anti-HBs Ag changes before or after Hepatitis B vaccination. The study was performed on C57BL6 mice ( $\mathrm{n}=25)$. The mice were divided into 3 groups. The control group was given the Hepatitis B vaccine 3 times with intervals of 3 weeks. Group 1 was administered JWH-018 (before) + Hepatitis B vaccine (after). Group 2 was treated Hepatitis B vaccine (before) + JWH-018 (after). Blood samples were collected at the end of the drug and vaccine administration. The control group's Anti-Hbs Ag titer mean was found to be lower than the mean of other groups. When the within-group data was evaluated, it was observed that there was a statistical difference between the data of Group $2(p=0,017)$. When Anti-Hbs AG titer was evaluated between group, it was observed that there was a statistical difference in the first ( $p$ $=0,018)$ and third measurements $(p=0,005)$. A total of 5 mice from the experimental groups died at different stages of the study. In this study, the use of JWH-018 has been shown to be effective on the anti-HBs parameter. In addition, we believe that the scientific value of our study will be possible by understanding the relationship between cannabinoid system and immune system.
\end{abstract}

Keywords: Hepatitis B, Immunity, JWH-018, Mice, Vaccination.

Öz: Sentetik kannabinoidler bağışıklık sistemini etkileyebilir ve bağışıklık tepkisinde bazı değişikliklere neden olabilir. Hepatit B aşısının oluşturduğu antikor yanıt üzerine sentetik kannabinoidlerin etkilerini inceleyen çalışma sayısı oldukça kısıtlıdır. Bu çalışmanın temel amacı, JWH-018'in Hepatit B aşılamasından önce veya sonra anti-HBs Ag değişiklikleri üzerindeki etkisini araştırmaktır. Çalışma, C57BL6 fareleri $(\mathrm{n}=25)$ üzerinde yapıldı. Fareler 3 gruba ayrıld1. Kontrol grubuna 3 hafta aralıklar ile 3 kez sadece Hepatit B aşısı uygulandı. Grup 1'e önce JWH-018 uygulandı sonrasında Hepatit B aşısı uygulandı. Grup 2'ye önce Hepatit B aşısı uygulandı sonrasında JWH-018 uygulandı. İlaç ve aşı uygulamasının sonunda kan örnekleri toplandı. Kontrol grubunun Anti-Hbs Ag titresi ortalamasının diğer grupların ortalamasından daha düşük olduğu bulundu. Grup içi veriler değerlendirildiğinde, Grup 2 verileri arasında istatistiksel bir fark olduğu gözlenmiştir $(p=0,017)$. Gruplararsı Anti-Hbs Ag titresi değerlendirildiğinde, birinci ( $(p=$ $0,018)$ ve üçüncü ölçümde $(\mathrm{p}=0,005)$ istatistiksel fark bulundu. Ayrıca, deney gruplarından toplam 5 fare, çalışmanın farklı aşamalarında öldü. Bu çalışmada, JWH-018 kullanımının anti-HBs parametresi üzerinde etkili olduğu gösterilmiştir. Çalışmamızın bilimsel değerinin kannabinoid sistem ile bağışıklık sistemi arasındaki ilişkiyi anlayamaya yardımcı olacağına inanıyoruz.

\begin{tabular}{ll}
\hline Anahtar Kelimeler: Hepatit B. Bağışıklık, JWH-018, Fare, Aşılama \\
\hline${ }^{*}$ Corresponding author : Serkan KÖKSOY & e-mail : skoksoy@mehmetakif.edu.tr \\
Geliş tarihi / Received : 30.12.2020 & Kabul tarihi / Accepted: 07.04.2021 \\
\hline
\end{tabular}

\section{Introduction}

Hepatitis B viruses can be prevented by vaccination (Hou et al., 2005; Thanavala et al., 2005). The vaccination has certain periods $(20 \mathrm{mcg}$ of HBs antigen at months 0-1-6) (Hwang et al., 2010). After 3 times vaccination, the antibody titer for seroconversion is considered $>10 \mathrm{mIU} / \mathrm{ml}$. (Florani et al., 2004). Many factors can affect seroconversion (drug addiction, aging, diseases etc) (Marsland et al., 2001). The immune response to the Hepatit B vaccine is complex and regulated by some genes (Milich et al., 2003). In addition, dendritic cells can initiate the immune response by 
presenting the antigen to $T_{h}$ and $T_{C}$. $T_{h}$ cells can stimulate B lymphocytes with various cytokines and secrete anti-viral cytokines such as IFN- $\gamma$, TNF- $\alpha$ (Chen et al., 2019, Koziel, 1998). Drugs used by substance addicts can affect the immune system ( $\Delta 9$-THC etc.). One of these drugs is JWH018 (structurally similar to $\Delta$ 9-THC) (Showalter et al., 1996). JWH-018 can stimulate the immune system through the endogenous cannabinoid system (ECS). ECS has two dominant receptors. These receptors help regulate functions in the central and peripheral nervous system (Matsuda et al., 1990; Munro et al., 1993). JWH-018 can stimulate both dominant receptors (Aung et al., 2000). The $\mathrm{CB}_{2}$ receptor can stimulate immune system cells and conduct immune modulation (Every-Palmer, 2011). Studies on hepatitis B vaccine antibody response and JWH-018 are extremely limited. The main purpose of this study was to investigate the effect of JWH-018 on antibody titration before and after the Hepatitis B vaccine.

\section{Materials and Methods}

\section{Animal Model}

All experiments were conducted in 25-30 g adult male C57BL/ 6 mice at the age of 8-10 weeks old. The mice were placed in standard plastic, steel cover and watery cages in the laboratory. Photoperiod, constant heat and humidity were applied by automatic mechanism. Food and water were provided ad libitum. Ethics Committee permission was obtained from Mehmet Akif Ersoy University Animal Experiments Local Ethics Committee (2017/268).

\section{Drug and Dose Selection}

There are studies reporting death associated with JWH-018 (1-naphthalenyl(1-pentyl-1H-indol-3yl)-methanone) (Cayman Chemical, CAS: 20941407-03) in the literature (Mir et al., 2011; HermansClausen et al., 2013). Considering the literature, the number of studies investigating the relationship between JWH-018 and Anti HBs Ag parameters is quite limited
Therefore, we prefered to use the first detected synthetic cannabinoid (JWH-018) in our study (EMCDDA, 2010). In this study, JWH-018 dose was selected based on previous studies in mice (Ossato et al., 2015). The dose of JWH-018 was considered $1 \mathrm{mg} / \mathrm{kg}$ intraperitoneal (i.p). Also, Engerix B (20 $\mu \mathrm{g} 1 \mathrm{ml})$ (GlaxoSmithKline) was determined as the Hepatitis $B$ vaccine. In a previous study using Engerix B the dose of this vaccine was determined as $2 \mu \mathrm{g}$ per capita for C57BL/ 6 mice. The dose for seroconversion was determined 3 times at intervals of three weeks (Sleijffers et al., 2002).

\section{Drug preparation and Treatment}

JWH-018 (1 mg / kg) was prepared in absolute ethanol $(1 \%)$ and salin (99\%). It was administered by i.p. injection ( $1 \mathrm{ml}, 30 \mathrm{G}, 8 \mathrm{~mm}$ ). Engerix $\mathrm{B}(20$ mg $1 \mathrm{ml}$ ) was administered intramuscular (i.m.) injection at a volume of $0.1 \mathrm{ml} /$ per capita by vehicle (30G, $8 \mathrm{~mm}$ ).

\section{Setting up Animal Groups}

Weight analysis was performed after dividing the mice into groups. The weights of control, group 1 and group 2 were measured (Respectively: $32.2 \pm 1.11 ; \quad 32.16 \pm 1,17 ; \quad 32.03 \pm 1.03$ gr and $\mathrm{p}=0.91)$. Mice were divided into 3 groups [(control group $(\mathrm{n}=7)$, group $1(\mathrm{n}=9)$ and group $2(\mathrm{n}=9)]$. The control group in this study will be used as a control for both group 1 and group 2 .

\section{Drug Administration}

Control group; it was immunized with Engerix B $(2 \mu \mathrm{g})$ at 3 times for 3-week intervals. Group 1; JWH-018 was administered once a week for 4 weeks. At the end of this period, $2 \mu \mathrm{g}$ Engerix B was immunized 3 times at 3 -week intervals. Group 2 ; it was immunized 3 times at 3 -weeks intervals with Engerix B $(2 \mu \mathrm{g})$. At the end of this period JWH-018 was administrated once a week for 4 weeks.

\section{Collection of blood samples}

Blood samples were collected from tail veins of animals by using heparinized syringe. $20 \mu \mathrm{l}$ of blood was collected from each mouse and it was 
collected 3 times with an interval of 2 weeks. Blood samples were added to $20 \mu \mathrm{l}$ of citrate buffer, which was previously placed in eppendorf tubes. Blood samples were centrifuged for 3 minutes at $3000 \mathrm{rpm}$ to separate the plasma. Plasma samples were stored at $20^{\circ} \mathrm{C}$ until assayed.

\section{ELISA}

$11 \mathrm{ml}$ of PBS (Merck) and $3.22 \mu \mathrm{l}$ of HBsAg protein (Fitzgerald 10 - 1324) were added to a falcon tube (Isolab). Out of which $100 \mu$ l of prepared PBS and HBS ag liquid was added to the tube, and covered with aluminum foil and stored in refrigator $\left(+4{ }^{\circ} \mathrm{C}\right)$. Next day, the plate was washed 3 times with PBS + Tween (Merck). $22 \mathrm{ml}$ of PBS and $110 \mathrm{mg}$ of BSA (Sigma-Aldrich) were added to other falcon tube and it was added to each well $200 \mu \mathrm{l}$ and incubated $\left(1 \mathrm{~h}\right.$ at $\left.37^{\circ} \mathrm{C}\right)$. The plate was washed 3 times with PBS + Tween. 1/100 plasma was added to wells and was incubated $1 \mathrm{~h}$ at $37^{\circ} \mathrm{C}$. After that it was washed 3 times with wash buffer. Alkaline phosphataselabeled of polyvalent antibody diluted in a ratio of 1:1000 was added to $100 \mu \mathrm{l}$ each well and incubated $\left(1 \mathrm{~h}\right.$ at $\left.37^{\circ} \mathrm{C}\right)$. Plate was washed $4-5$ times with a washing buffer. $100 \mu \mathrm{l}$ pNPP (Merck) prepared in substrate buffer was added to each well and incubated for 30 minutes. The absorbance was measured with an ELISA reader at $405 \mathrm{~nm}$ after 30 minutes of incubation

\section{Statistical Analysis}

The analysis of the data was done with the SPSS program (Version 22, IL, USA). Descriptive parameters were represented $\mathrm{n}$, mean \pm standard deviation (Mean \pm Sd). ANOVA test was performed to compare the groups. Post-hoc Tukey test was performed to determine in which group the statistical difference originated from. The Tukey test was represented in the table with a "letter" (Different letters represent significant difference between sub-groups). A p-value less than $0.05(\mathrm{p} \leq 0.05)$ was considered as statistically significant.

\section{Results}

Anti-HBS Ag measurements of the control groups were on mean lower than group 1 and group 2 .
Also, totaly 5 mice died in experimental (Group 12) groups.

Within-Group Comparison: Statistical difference was not detected in both control group and group $1(\mathrm{p}>0.05)$. The final measurement $\left(3^{\text {th }}\right)$ of the Group 2 was higher than other measures $\left(1^{\text {th }}\right.$ and $\left.2^{\text {nd }}\right)$ and was statistically significant $(\mathrm{p}<0.05)$.

Between Groups Comparison: Statistical difference was measured in the first and third measurements of the groups $(p<0.05)$.

Table 1: Anti HBs Ag parameters comparison within groups

\begin{tabular}{lllll}
\hline Group & Measure & $\mathbf{n}$ & Mean \pm Sd $^{*}$ & $\mathbf{p}$ \\
\hline \multirow{3}{*}{ Control } & $1^{\text {th }}$ & 7 & $0.61 \pm 0.10 \mathrm{a}$ & \\
& $2^{\text {nd }}$ & 7 & $0.61 \pm 0.11 \mathrm{a}$ & 0.896 \\
& $3^{\text {th }}$ & 7 & $0.64 \pm 0.10 \mathrm{a}$ & \\
\hline \multirow{3}{*}{ Group 1 } & $1^{\text {th }}$ & 6 & $1.23 \pm 0.38 \mathrm{a}$ & \\
& $2^{\text {nd }}$ & 6 & $1.03 \pm 0.57 \mathrm{a}$ & 0.752 \\
& $3^{\text {th }}$ & 6 & $1.18 \pm 0.40 \mathrm{a}$ & \\
\hline \multirow{3}{*}{ Group 2 } & $1^{\text {th }}$ & 7 & $0.78 \pm 0.24 \mathrm{a}$ & \\
& $2^{\text {nd }}$ & 7 & $0.78 \pm 0.24 \mathrm{a}$ & 0.017 \\
& $3^{\text {th }}$ & 7 & $1.20 \pm 0.35 \mathrm{~b}$ & \\
\hline
\end{tabular}

*OD: $405 \mathrm{~nm}$

Table 2: Anti HBs Ag parameters comparison between groups

\begin{tabular}{lllll}
\hline Group & Measure & $\mathbf{n}$ & Mean $\pm \mathbf{S d}^{*}$ & $\mathbf{p}$ \\
\hline Control & & 7 & $0.61 \pm 0.10 \mathrm{ab}$ & \\
Group 1 & $1^{\text {th }}$ & 6 & $1.23 \pm 0.38 \mathrm{a}$ & 0.018 \\
Group 2 & & 7 & $0.78 \pm 0.24 \mathrm{~b}$ & \\
\hline Control & & 7 & $0.61 \pm 0.11 \mathrm{a}$ & \\
Group 1 & $2^{\text {nd }}$ & 6 & $1.03 \pm 0.57 \mathrm{a}$ & 0.123 \\
Group 2 & & 7 & $0.78 \pm 0.24 \mathrm{a}$ & \\
\hline Control & & 7 & $0.64 \pm 0.10 \mathrm{a}$ & \\
Group 1 & $3^{\text {th }}$ & 6 & $1.18 \pm 0.40 \mathrm{~b}$ & 0.005 \\
Group 2 & & 7 & $1.20 \pm 0.35 \mathrm{~b}$ & \\
\hline
\end{tabular}

*OD: $405 \mathrm{~nm}$

\section{Discussion}

Hepatitis B is a major public health problem. Many people have been infected with this disease. It is estimated that around 350 million people carry HBV (Kuo et al., 2004). It is possible to prevent the disease with the vaccine. When the antibody titer is higher than $10 \mathrm{mIU} / \mathrm{ml}$, it is considered as 
seroconversion (Floreani et al., 2004). There are factors that affect seroconversion. These factors include immunosuppressive diseases, aging, etc (Marsland et al., 2001). JWH-018 is an addictive material that acts on the endogenous cannabinoid system (ECS). ECS has two dominant receptors. These receptors help regulate functions in the central and peripheral nervous system (Matsuda et al., 1990; Munro et al., 1993). JWH-018 stimulate both $\mathrm{CB}_{1}$ and the $\mathrm{CB}_{2}$ receptor (Aung et al. 2000). Compared to THC, this effect remains lower (Showalter et al., 1996). ECS can play immunmodulatory role on the immune system (Kleain and Cabral, 2006). This role is dosedependent and can lead to immunosuppression or immunproliferation in immune cells (Croxford and Yamamura, 2005). Very few studies focused or investigated on the relationship between antiHBs Ag and JWH-018. Because of that we thought that it was an important topic to investigate. The main purpose of this study was to investigate the effect of JWH-018 on the anti-HBs Ag parameter.

During the study, 5 mice from the experimental groups (Group 1 and Group 2) were died. No death occurred in mice from control group. In the literature, it has been reported that JWH-018 is toxic and deadly for humans (Labay et al., 2016). Also, there are studies reporting death associated with JWH-018 (Mir et al., 2011; HermannsClausen et al., 2013). But similar studies did not report death in various doses (Marshell et al., 2014, Mutluay et al., 2019). In our study, the mice died just in the experimental groups, but it did not die in the control group.

Therefore, we think that the deaths may be related to the dose of JWH-018. We were evaluated antiHBs Ag parameter within-groups and between groups. In all measurements, mean of control group was lower than both group 1 and group 2 . In our study, mean anti $\mathrm{Hbs} \mathrm{Ag}$ titer of the control group was measured in the range of 0.61-0.64 OD. Anti-HbsAg mean of various study were measured in the range of $0.4-0.6$ OD (Li et al., 2014, Wu et al., 2016). The data obtained from the control group of our study is supported by other studies in the literature. We could not find any study supporting that the mean of the experimental groups was higher than the control group. We are suggesting that this situation may be related to immune response mechanisms (against both vaccines and viruses).

The first immune response to Hepatitis B Virus is known to be given by Natural Killer (NK) cells. NK cells stimulate various $\mathrm{T}$ lymphocyte cells by secreting IFN- $\gamma$ (Kakimi et al., 2000). DC present antigen to Th and Tc. Th cells secrete cytokines (IL-4, IL-10, TNF $\alpha$ etc.) that activate B lymphocytes to create an immune response (Chen et al., 2019). In vaccine-specific response, antigenspecific $B$ and $T$ lymphocytes and various cytokines are known to play roles (Filippelli et al., 2014).

JWH-018 is structurally similar to THC. Studies on THC have shown that THC has a suppressor effect on immune system cells (Eisenstein snd Meissler, 2015; Roth et al., 2015). THC and other cannabinoids have immunosuppressive effect in both in vivo and in vitro studies (NK, DC, macrophage, mast cells B and T lymphocytes etc.) (Samson et al., 2003; Do et al., 2004). Another study has shown that B lymphocytes induce transition from IgM to IgE (Agudelo et al., 2008). But in another study, synthetic cannabinoids have proliferative effect on B cells, NK and neutrophils (Lee et al., 2001). In a study about the use of THC (marijuana smokers) and Hepatitis B vaccine, antiHBs Ag parametres of marijuana smokers and non-smokers were compared. However, it was observed that difference between them was not statistically significant (Kiertscher et al. 2018).

\section{Conclusion}

This study showed that JWH-018 was effective on anti-HBs Ag parameter. Low mean of anti-HBs $\mathrm{Ag}$ level in control group was appropriate for our two-way hypothesis. In general, orginal articles show that synthetic cannabinoids are responsible for suppression of immune system cells. However, very few studies have reached result of immunproliferation. We think that our study is very valuable in terms of proving the relationship between JWH-018 and Anti-Hbs parameter. However, further studies need to be done to understand causation. 


\section{Acknowledgement}

This study was derived from the first author's Master Thesis, supported by Burdur Mehmet Akif Ersoy University Scientific Research Projects Coordination Unit (Project Number: 0423-YL-17)

\section{References}

Agudelo, M., Newton, C., Widen, R., Sherwood, T., Nong, L., et al. 2008. Cannabinoid receptor 2 (CB2) mediates immunoglobulin class switching from $\operatorname{IgM}$ to $\operatorname{IgE}$ in cultures of murine-purified $B$ lymphocytes. J Neuroimmunol., 3(1), 35-42. DOI:10.1007/s11481-007-9088-9

Aung, M.M., Griffin, G., Huffman, J.W., Wu, M., Keel, et al. 2000. Influence of the N-1 alkyl chain length of cannabimimetic indoles upon $\mathrm{CB}(1)$ and $\mathrm{CB}(2)$ receptor binding. Drug Alcohol Depend, 60(2), 133-140. DOI:10.1016/s0376-8716(99)00152-0

Chen, L., Zhang, Y., Zhang, S., Chen, Y., Shu, X., et al. 2019. A novel T-cell epitope in the transmembrane region of the hepatitis B virus envelope protein responds upon dendritic cell expansion. Arch Virol., 164(2), 483-495. https://doi.org/10.1007/s00705-018-4095-0

Croxford, J.L., \& Yamamura, T. 2005. Cannabinoids and the immune system: potential for the treatment of inflammatory diseases?. J Neuroimmunol., 166(1-2),318. DOI:10.1016/j.jneuroim.2005.04.023

Do, Y., McKallip, R.J., Nagarkatti, M., Nagarkatti, P.S., 2004. Activation through cannabinoid receptors 1 and 2 on dendritic cells triggers NF- $x \mathrm{~B}$-dependent apoptosis: novel role for endogenous and exogenous cannabinoids in immunoregulation. J Neuroimmunol. 173(4):2373-2382. DOI: 10.4049/jimmunol.173.4.2373

Eisenstein, T.K., \& Meissler, J.J., 2015. Effects of Cannabinoids on T-cell Function and Resistance to Infection. J Neuroimmune Pharmacol, 10(2),204-216. DOI:10.1007/s11481-015-9603-3

EMCDDA., 2010. Annual report on the state of the drugs problem in Europe, Lisbon.

Every-Palmer, S. 2011. Synthetic cannabinoid JWH018 and psychosis: an explorative study. Drug Alcohol Depend, 117(2-3):152-157. DOI: 10.1016/j.drugalcdep.2011.01.012.

Filippelli, M., Lionetti, E., Gennaro, A., Lanzafame, A., Arrigo, T., et al. 2014. Hepatitis B vaccine by intradermal route in non responder patients: an update. World J Gastroenterol, 20(30), 10383 10394. DOI:10.3748/wjg.v20.i30.10383
Floreani, A., Baldo, V., Cristofoletti, M., Renzulli G., et al. 2004. Long-term persistence of anti-HBs after vaccination against $\mathrm{HBV}$ : an 18 year experience in health care workers. Vaccine., 22(5)6,607- 610. DOI: 10.1016/j.vaccine.2003.09.001

Hermanns-Clausen, M., Kneisel, S., Szabo, B., Auwärter, V. 2013. Acute toxicity due to the confirmed consumption of synthetic cannabinoids: clinical and laboratory findings. Addiction (Abingdon, England), 108(3):534-544.

0443.2012.04078.x

Hou, J., Liu, Z., Gu, F. 2005. Epidemiology and prevention of hepatitis B virus infection. Int J Med Sci., 2(1),50-57. DOI:10.7150/ijms.2.50

Hwang, L., Y., Grimes, C.,Z., Tran, T.Q., Clark, A., et al. 2010. Accelerated hepatitis B vaccination schedule among drug users: a randomized controlled trial. The Journal of Infect ious Diseases., 202(10),15001509. DOI: $10.1086 / 656776$

Kakimi, K., Guidotti, L.G., Koezuka, Y., Chisari, F.V. (2000). Natural killer $\mathrm{T}$ cell activation inhibits hepatitis B virus replication in vivo. J Exp Med., 192(7), 921-930. DOI:10.1084/jem.192.7.921

Kiertscher, S.M., Gangalum, P.R., Ibrahim, G., Tashkin, D.P., Roth, M.D. 2018. A Prospective Study of Humoral and Cellular Immune Responses to Hepatitis B Vaccination in Habitual Marijuana Smokers. J Neuroimmune Pharmacol., 13(2), 219-229. DOI:10.1007/s11481-018-9776-7

Klein, T.W., Cabral, G.A. 2006. Cannabinoid-induced immune suppression and modulation of antigenpresenting cells. J Neuroimmune Pharmacol., 1(1),5064. DOI:10.1007/s11481-005-9007-x

Koziel, M. J. (1998). The immunopathogenesis of HBV infection. Antivir Ther., 3(Suppl 3), 13-24. PMID: 10726052

Kuo, I., Sherman, S.G., Thomas, D.L., Strathdee, S.A. 2004. Hepatitis B virus infection and vaccination among young injection and non-injection drug users: missed opportunities to prevent infection. Drug Alcohol Depend., 73(1), 69-78. DOI:10.1016/j.drugalcdep.2003.10.007

Labay, L.M., Caruso, J.L., Gilson, T.P., Phipps, R.J., Knight, L. et al. 2016. Synthetic cannabinoid drug use as a cause or contributory cause of death. Forensic Sci Int, 260, 31-39. DOI: 10.1016/j.forsciint.2015.12.046

Lee, S. F., Newton, C., Widen, R., Friedman, H., Klein, T.W. 2001. Differential expression of cannabinoid $\mathrm{CB}(2)$ receptor $\mathrm{mRNA}$ in mouse immune cell subpopulations and following B cell stimulation. 
Eur J Pharmacol., 423(2-3), 235-241. https://doi.org/10.1016/s0014-2999(01)01122-0

Li, P., Tan, H., Xu, D., Yin, F., Cheng, Y., et al. 2014. Effect and mechanisms of curdlan sulfate on inhibiting $\mathrm{HBV}$ infection and acting as an $\mathrm{HB}$ vaccine adjuvant. Carbohydrate Polymers, 110, 446-455. DOI:10.1016/j.carbpol.2014.04.025

Marshell, R., Kearney-Ramos, T., Brents, L.K., Hyatt, W.S., Tai, S., et al. 2014. In vivo effects of synthetic cannabinoids JWH-018 and JWH-073 and phytocannabinoid $\Delta 9$-THC in mice: inhalation versus intraperitoneal injection. Pharmacology, Biochemistry, and Behavior, 124, 40-47. DOI:10.1016/j.pbb.2014.05.010

Marsland, A.L., Cohen, S., Rabin, B.S., Manuck, S.B. 2001. Associations between stress, trait negative affect, acute immune reactivity, and antibody response to hepatitis B injection in healthy young adults. Health Psychol., 20(1),4-11., PMID: 11199064.

Matsuda, L.A., Lolait, S.J., Brownstein, M.J., Young, A.C., Bonner, T.I. 1990. Structure of a cannabinoid receptor and functional expression of the cloned cDNA. Nature, 346(6284), 561-564. DOI:10.1038/346561a0

Milich, D.R., \& Leroux-Roels, G. G. 2003. Immunogenetics of the response to $\mathrm{HBsAg}$ vaccination. Autoimmunity Reviews, 2(5),248-257. DOI:10.1016/s1568-9972(03)00031-4

Mir, A,, Obafemi, A., Young, A., Kane, C. 2011. Myocardial infarction associated with use of the synthetic cannabinoid K2. Pediatrics. 128(6):e1622e1627. DOI:10.1542/peds.2010-3823

Munro, S., Thomas, K.L., Abu-Shaar, M. 1993. Molecular characterization of a peripheral receptor for cannabinoids. Nature, 365(6441), 61-65. DOI:10.1038/365061a0

Mutluay, D., Güngör, Ş., Tenekeci, G. Y., Köksoy, S., Çoban, C. S. 2019. Effects of synthetic (JWH-018) cannabinoids treatment on spermatogenesis and sperm function. Drug and chemical toxicology, 1-8. DOI:10.1080/01480545.2019.1680686

Ossato, A., Vigolo, A., Trapella, C., Seri, C., Rimondo, C., et al. 2015. JWH-018 impairs sensorimotor functions in mice. Neuroscience, 300, 174-188. DOI:10.1016/j.neuroscience.2015.05.021

Roth, M.D., Castaneda, J.T,, Kiertscher, S.M., 2015. Exposure to $\Delta$-tetrahydrocannabinol impairs the differentiation of human monocyte-derived dendritic cells and their capacity for T cell activation. J Neuroimmune Pharmacol., 10(2):333-343. DOI: 10.1007/s11481-015-9587-z

Showalter, V.M., Compton, D.R., Martin, B.R., Abood, M.E. 1996. Evaluation of binding in a transfected cell line expressing a peripheral cannabinoid receptor (CB2): identification of cannabinoid receptor subtype selective ligands. J Pharmacol Exp Ther., 278(3), 989-999.

Sleijffers, A., Garssen, J., de Gruijl, F. R., Boland, G. J., van Hattum, J., van Vloten, W. A., \& van Loveren, H. 2002. UVB exposure impairs immune responses after hepatitis $\mathrm{B}$ vaccination in two different mouse strains. Photochem Photobiol, 75(5), 541-546. DOI:10.1562/00318655(2002)075<0541:ueiira > 2.0.co ;2

Samson, M.T., Small-Howard, A., Shimoda, L.M., Koblan-Huberson, M., et al. 2003. Differential roles of CB1 and CB2 cannabinoid receptors in mast cells. J Neuroimmunol. 170(10):4953-4962. DOI: 10.4049/jimmunol.170.10.4953.

Thanavala, Y., Mahoney, M., Pal, S., Scott, A., et al. 2005. Immunogenicity in humans of an edible vaccine for hepatitis B. Proc Natl Acad Sci., 102(9),3378-3382. DOI: 10.1073/pnas.0409899102

Wu, Y., Li, S., Li, H., Zhao, C., Ma, H., et al. 2016. Effect of a polysaccharide from Poria cocos on humoral response in mice immunized by H1N1 influenza and HBsAg vaccines. Int J Biol Macromol., 91, 248-257. DOI:10.1016/j.ijbiomac.2016.05.046 